\title{
ICT based Brain-Compatible Teaching in Adult Education
}

\author{
P.Caroline Cynthia , V. David Jeyabalan
}

\begin{abstract}
We live in an age where many of us are wellgrounded in the field of education. It is evident that the adult learners are deeply entrenched by the use of technology in their everyday learning. The quality of education has progressed towards a learner- centered approach where the students are given more opportunities to self-learn subjects of their choice. By implementing Brain-Compatible teaching and learning methods with the use of Information and Communication Technology ( ICT) teachers can make their practices more professional and help adult learners meet their optimal level of learning a language to a greater extent. In this context, the study attempts to explore how teachers can make lesson content relevant for students with ICT tools. The main objective of this paper explains how English language teachers can help the adult learners in learning the real world English with the use of technology. Using qualitative method the collected data provides an overview of how the students are benefited and given opportunities to improve their knowledge in a productive way. The article gives an outline of how the use of technology by the students has highly developed their interpersonal skills, social skills and communicative skills which are the need of the hour..
\end{abstract}

Keywords - Adult and Continuing Education, Adult Learners, Brain - Compatible Teaching, Information and Communication Technology (ICT), Professional Development..

\section{INTRODUCTION}

In education, the teaching and learning process of adult learners are quite different from that of young learners. The need of learning a context or a scenario varies among every individual adult learner. The use of technology in the field of education keeps extending almost every day. It's a wellknown fact that teachers play a significant role in providing learners with new perspectives and understandings on the changes subsisting in technology. Brain-Compatible teaching is one such appropriate approach, where teachers can attempt to implement challenging and innovative tasks to make learning more comprehensive. Brain- based teaching is a new paradigm that helps teachers to try, explore, self-learn, modify and self-reflect their own teaching which will lead to a natural process of evaluation.

Self -Observation and Self-evaluation are two essential components a reflective teacher should contemplate for creating a better learning environment. "Reflection...refers to the capacity of a teacher to think creatively, imaginatively and at times, self-critically about classroom practice" (Lasley, 1992). It is essential for a teacher to ensure whether the learners are able to fearlessly learn difficult topics or face the classroom challenges with ease. A reflective

Revised Manuscript Received on September 14, 2019.

Dr.P.Caroline Cynthia , Bannari Amman Institute of Technology , Anna University, Coimbatore, Tamil Nadu, India.(E-mail: dr.carolinecynthia@gmail.com)

Dr.V. David Jeyabalan, Loyola College, University of Madras, Chennai, Tamil Nadu, India. (E-mail: davidjbalan@yahoo.com) teacher teaches, self-access practices, receives feedback and teaches the same content over again effectively as each student's learning differs. Ceaseless efforts on practicing the above mentioned methods not only help teachers to cope with the expectations of the learners but also improve the quality of their teaching methods both personally and professionally.

Reading and Adult Continuing learning are closely interrelated with each other. Habitual reading can help teachers to master a variety of new concepts that keeps the brain active and engaging. Being articulate and well-spoken is one of the finest qualities millennial learners should obtain to boost their self-esteem and self-confidence. Teaching the art of reading with ICT tools apparently improves vocabulary, critical thinking and concentration of learners which in turn would ameliorate the speaking and writing fluency. Comprehending a given text not only improves the development of mind, but also empowers a teacher to make changes and build on a unique style in his/her teaching. ICT tools in form of Wi-Fi, Internet, SMART Board, Pen Drive, Mobile Phones, Laptop and Tablet can trigger the interest of learners than the chalk and talk method.

With the use of ICT, teachers can practice different learning styles to improve the critical thinking skills of the learners. To be specific, teachers can incorporate technology in three main learning styles such as Visual learning, auditory learning and kinesthetic learning. It's a well-known fact that brain-based learning helps students learn better. Marilee Sprenger (2010), terms the 21 st century learners as "digital brains". She also emphasis that technology tools help learners to understand and relate the meaning of the content better than the traditional methods of learning. She highlights that students have a strong desire to use digital devices in their language learning thus; it's noticeable that teachers' relationships with digital instruments build stronger relationships with students as well.

"Language anxiety can originate from learners' own sense of 'self', their self-related cognitions, language learning difficulties, differences in learners' and target language cultures, differences in social status of the speakers and interlocutors, and from the fear of losing self-identity" (Masoud Hashemi, 2011). In order to help the weak learners confront anxiety in language learning, teachers need to create an anxiety-free classroom environment by providing a variety of learning materials with novelty and 
challenges. In terms of English language teaching, teachers providing context beyond the need and off the subjects can also cause stress and learning difficulties among them. Mobile application such as Quizlet, Kahoot, Google Drive, Webinar and Padlet can help teachers ease such situations and continuously engage students effectively by making their responses digital.

According to Merriam and Brockett (2007), the definition of an adult learner depends on who you are teaching, where you are teaching and the general context of what you are teaching. In today's modern world, teachers cannot force or expect adult learners to memorize and repeat as it doesn't result in higher-level or critical thinking. Most of the time, memory is not a reliable indicator of intelligence. Teachers can help learners think by providing new learning materials than outdated materials. "Activities intentionally designed for the purpose of bringing about learning among those who age, social roles, or self-perception define them as adults" (Merriam \& Brockett, 2007). It is evident that readiness and willingness to learn new things occurs to an adult learner whenever they are provided with interesting learning materials. Another factor to consider is that brain based learning not only creates an impact but also leads a lasting impression in the minds of the learners.

\section{REVIEW OF LITERATURE}

\section{A. Brain Based Learning}

A.A. Mohamed S Salem (2017), is of the opinion that brain based learning is an effective approach for developing listening skills. He states that implementing brain based learning both inside and outside the classrooms improves teachers' teaching skills and optimizes students' learning. A total of 36 second year Egyptians business majors in the college of business administration participated in testing their listening and vocabulary retention test. Using quantitative approach the data was collected using multiple choice pre and post questionnaire. The results revealed that the brain based listening and vocabulary retention improved the ESP university students to a great extent. Findings also revealed that a positive attitude towards language learning was stemmed from intrinsic and extrinsic motivation triggered through interesting activities used in the class.

According to Parastoo A Oghyanous (2017), brain-based teaching for adult learners has shown remarkable results on understanding students' self-efficacy. It has also benefited both the students and EFL teachers in their teaching and learning process. He emphasizes that teachers play a greater role in providing a comfortable learning atmosphere for the students. He believes that brain-based learning helps learners to focus and improve brain functionality of every individual learner. A sample of 90 young EFL learners were selected and divided into an experimental group and control group. Using Flyers Test, language skills such as Listening (25 questions), Reading and writing (50 questions), and Speaking (10 minutes) (LSRW) were assessed in accordance to CEFR level. The result revealed that brain-based teaching created a great impact among the learners' beliefs in the context of language learning.

Gabriel Savonitti and Joao Mattar (2018), explored how game based teaching improved the motivation level of learners, classroom interaction, social interaction through games, tangential learning, grades, complementary material, vocabulary, repetitive written content, big written content, text interpretation, audio and text. He reviews Gardner, Brown, and Ryan e Deci's opinion on game based teaching and learning method. He reiterates that the use of games in the classroom can generate students' engagement. He also states and recommends continuous intrinsic motivation can be achieved if the students are given challenging and creative tasks both inside and outside the classroom.

\section{B. ICT and Teacher Development}

According to Mabel CPO Okojie et al., (2006), the scope of technology in education depends mainly on the teacher's perception on the use of technology. In this study, they had explored the reasons, problems and difficulties teachers face in the use of technology. More importantly, the researchers focused on encouraging teachers to use technology in order to be reflective practitioners inside the classroom. They briefly outlined that ICT would help teachers to implement a variety of ideas, methods and evaluation easier than the traditional ways. They also insisted that teachers should engage students in an exploratory learning environment which would stimulate higher thinking skills among the teachers as well as learners. They concluded by stating that there would be a lot of scope for technology enhanced learning environment, if teachers make the best use of existing ICT tools, equipment and materials for productive teaching and learning process.

According to Jeremy Fox (1984), computer-assisted vocabulary learning exercises give a rich and stimulating learning environment for learners to develop their reading and writing skills. He conducted his experiment with a group of pilots from the United Arab Emirates. He provided them with different vocabulary exercises where each activity had its own method of practice. The findings of the study showed that the students were impressed with the use of computers in vocabulary teaching. The writer expressed that every English teacher should accept computer as an information source and not as a skill master. He also suggested the teachers to accept the computer as a medium which offers new opportunities for innovative method for teaching and learning.

Agelii \& Gronlung. A (2013) in their study have claimed that reading and writing should be practiced from the early ages of language learning. The central theme of the study was to develop a new method for testing the reading and writing skills of the students. With regard to that, the researchers developed a project called iWRT (integrated Write and Learn) method with a cognitive (learning to read) and a motor (learning to write) to identify the growth of the reading and writing skills of the learners and to improve their language learning. ICT tools such as keyboard, speech technology, Google docs for sharing texts and discussion were used to support the study. The target group found the use of keyboard and speech technology in writing and 62

Blue Eyes Intelligence Engineering

\& Sciences Publication 
speaking more interesting than a book and a paper. The study was a quasi-experiment with a test group of 46 students of 1 st grade classes from Sollentuna, Sweden. The findings of the research showed that the students performed well in reading and writing skills and the teachers found that the students have gained good confidence. The study also showed that the target groups were more excellent readers than the controlled group. In brief, the study had paved way for innovative as well as theory-based method for effective language learning.

\section{BACKGROUND THEORY}

\section{Web Tools}

Web learning creates a great impact on learners ${ }^{\text {ee }}$ way of thinking, behavior, learning, analyzing and understanding. Web 1.0 is a large scale website that is one-way broadcasting with specially formatted documents using Hyper Text Markup Language (HTML). Web 2.0 tools are very useful to share information and communicate to anyone at any time anywhere. The main advantage of using Web 2.0 in education is the level of increased opportunities for interaction and creativity.

Web 2.0 tools focus on helping learners to collaborate, share information, communicate and create flexible learning environment which are the 21 st century skills that digital natives expect from learning. The role of teacher in the use of Web 3.0 focuses on providing virtual learning materials using open resources. It also focuses on student's use of semantic profile of resources, social network communication profile, individual educational needs and monitoring and interaction style of the learners. Teachers can use Web 3.0 tools for social interaction with colleagues, peers and social partners for professional experience exchange.

In a Virtual Learning environment, interaction in the classroom between teachers and students adds a better personal touch than in a regular class teaching. Virtual learning allows the teacher to work with students so that the teacher gets the chance to understand the learning ability of the students within a short period of time.

\section{METHODOLOGY \& RESULTS}

This paper discusses in detail the research methodology applied in this study on how Information and Communication Technology (ICT) is used as an effective Brain- Compatible Teaching tool in adult education. The sample group of the present study consisted of a total of forty six teacher trainees from Stella Matutina College of Education, Chennai. The main aim of the two weeks program was to identify how the use of ICT tools to teach English created a strong impact among the minds of the preservice teachers. The literature review and background theory gives a clear direction to identify the exact research methodology to be followed for this study. Based on the qualitative research, information, opinion and feedback on the use of ICT were discussed using one -to-one interviews and open questions where the pre-service teachers were allowed to respond choosing their own words.
The pre-service teachers were given two hour training for fifteen days with an aim to understand how Google Classroom and Kahoot!, Augmented Reality, Liveboard Real Time Interactive Whiteboard, Google Classroom, Quizlet and Podcast applications can help teachers create an effective brain-based learning environment both inside and outside the classroom. The sample teachers were instructed to visit Kahoot! webpage and were guided to sign up in the login page. Since this training session can work well in a group, the sample teachers were divided into equal groups. One sample teacher in each group played the role of a teacher and the rest were students.

The sample teachers were asked to install Kahoot! application in their Smartphones for easy access. After the activation of the Kahoot! application, the sample teachers were asked to set quiz questions for a topic of their own. Since the application provides access pin for every activity, the teacher sets for his/her learner who can be shared with for taking the test. Once the students have taken the assigned test given by the teacher, the application displayed the name of the students with the total number of correct answers on the teacher's board. Thus these effective features in Kahoot! application helped the teacher to identify the strong and the weak learner in his/her class and always kept the learner engaged until the task ends.

This application works better with Google classroom application which is also a great tool which has similar features like Kahoot! The activities shared in Google Classroom application will habitually record the tasks provided by the teacher from the start of their academic teaching. Thus it helps the teachers to keep a record of his/her classes and also track the different methods of teaching he/ she has practiced in the classroom. This application can also serve the purpose of simplifying the lesson plan work.

\section{Augmented Reality}

The sample teachers were instructed to install augmented reality application in their Smartphones and Tablets. This task was done with individual teachers as it has many interesting pictures. This application can convert any surface as a projector and can display the image directly from the phone. The sample teachers were so excited to use their favorite characters in the wall. The sample teachers were given an activity to use augmented images and recite a story. The sample teachers enjoyed working with this application and they believed that this application would certainly impress young children in language classroom. They were also suggested to use similar augmented applications such as Holo, Quiver and Dinosaur Everywhere, to make class and storytelling activity interesting.

\section{E Liveboard Real Time Interactive Whiteboard}

The pre-service teachers were instructed to bring their laptops for practicing this activity. The class was divided into equal groups. The activity focused on the different ways 
to use Liveboard Real Time Interactive Whiteboard application. The pre-service teachers practiced this activity with the use of their own smartphones. They were guided to understand the meaning of icons and its uses, to attach images from image folder, to open an online chat for interaction, to share live broadcast from one device to another device. The sample teachers were found to be highly motivated by the use of this application on their own

\section{F Quizlet and Podcast}

The aim of the training was to give the sample teachers an augmented learning environment for their students. The sample teachers were instructed to install Quizlet and Pinterest applications and were asked to sign in the webpage. These applications are user-friendly the sample teachers were feeling comfortable in using it. The sample teachers were asked to search for topics that interest them and they were asked to share the images or videos, inspirational quotes in their pin boards. Since plenty of images, videos and links could be opened likeminded people who could comment on the pictures shared their views, thus acting as a forum for teachers to communicate.

In both applications the teachers could create their own sets of vocabulary based on the syllabus. Quizlet has interesting features like spell check, pronunciation, test sheet, match the following etc. Hence, any topic or subject words can be learnt using both the applications. These applications help teachers to have collection of all types of words for any kind of learners. The sample teachers were given an activity to use Pinterest in decorating their classroom with ideas shared in the application. They were provided with a theme and were instructed to pin their thoughts, ideas, and images into year board theme thus, this activity acted as a collection of yearbook vocabulary. Such creative activities can help learners to recall all the vocabulary learnt in an academic year. The aim of this activity was to help teachers to create a creative teaching and learning environment for both teachers and students.

In this session the sample teachers were introduced to the use of podcast tool Garage Band application. The sample teachers were divided into groups to practice reading and speaking skills. They were provided with printed dialogues from a short story that had five characters. The teachers were encouraged to record the given dialogues in their own voices. A short presentation on the use of podcasts and creative ways to use it was presented to all the sample teachers. Garage Band, an iOS supported application, is designed for music lovers but this application has a lot of features that can help English teachers to be creative in teaching storytelling activity for adult learners. Noticeable voice features such as dreamy voice, Telephone instruction voice, Robot voice, chipmunk voice and Monster voice. Use of such features in storytelling can help teachers to impress and engage the learners to a great extent that results in an active learning environment.

\section{CONCLUSION}

The advancements in technology have actually triggered the expectations of the present generation learners as the digital technology and ICT have created a great impact among the users. Virtual learning environment has transcended time and space of the present age learner as it creates a new world of learning that triggers the interest and creativity of every learner who experiences it. In such a scenario and also to face these challenges, teachers should ensure that the contents shared inside and outside the classrooms lead to a meaningful, productive learning environment..

\section{REFERENCES}

1. Bella, J., "Reflective Analysis of Student Work: Improving Teaching through Collaboration", New Delhi, India: SAGE , pp. 24, 2004.

2. Sprenger, M.,"Brain-Based Teaching in the Digital Age," ASCD, pp. 5-10, 2010.

3. Hashemi, M., "Language Stress And Anxiety Among The English Language Learners", Elsevier, Vol. 30, pp. $1811-1816,2011$.

4. Merriam, B. and Brockett, "The Profession and Practice of Adult Education: An Introduction", San Francisco, CA, Wiley, 2007.

5. Salem, Ashraf., "Engaging ESP Students with BrainBased Learning for Improved Listening Skills, Vocabulary Retention and Motivation". English Language Teaching, 2017.

6. Oghyanous, P., "The Effect of Brain-Based Teaching on Young EFL Learners' Self-Efficacy", English Language Teaching, Vol. 10, no. 5, pp. 1916-4742, 2017.

7. Savonitti, G ., and Mattar, J., "Entertainment Games for Teaching English as a Second Language: Characteristics and Potential". 2018.

8. Okojie, M. CPO et al., "The Pedagogy of Technology Integration", The Journal of Technology Studies, Vol. 32, no. 2, pp. $66-71,2006$.

9. Fox, J. , "Computer-Assisted Vocabulary Learning". ELT Journal, Vol. 38 no. 1, pp. 27-33, 1984.

10. Agelii., \& Gronlung. A., "Closing the gaps Improving literacy and mathematics by ICT-enhanced collaboration. Computers \& Education” pp. 99, 2013. 